\title{
ANALISIS PERBADINGAN PERKUATAN JEMBATAN RANGKA BAJA DENGAN METODE PRATEGANG EKSTERNAL DITINJAU DARI BENTUK TRASE KABEL PRATEGANG
}

\author{
Nicholas Hadi ${ }^{1}$ dan Edison Leo ${ }^{2}$ \\ ${ }^{\text {I} P r o g r a m ~ S t u d i ~ S a r j a n a ~ T e k n i k ~ S i p i l, ~ U n i v e r s i t a s ~ T a r u m a n a g a r a, ~ J l . ~ L e t j e n ~ S . ~ P a r m a n ~ N o .1 ~ J a k a r t a ~}$ \\ Email: nicholashadi@yahoo.com \\ ${ }^{2}$ Program Studi Sarjana Teknik Sipil, Universitas Tarumanagara, Jl. Letjen S. Parman No.1 Jakarta \\ Email: edisonl@ft.untar.ac.id
}

\begin{abstract}
ABSTRAK
Jembatan merupakan suatu struktur penting dalam infrastruktur jalan raya yang berfungsi untuk menghubungkan suatu ruas jalan yang terputus karena suatu rintangan. Rintangan tersebut biasa berupa sungai, jurang, lembah, atau danau. Di zaman modern ini, sedang dilaksanakan pembangunan di berbagai sektor, seperti ekonomi, sosial, dan industri. Hal ini menyebabkan terjadinya peningkatan beban pada jembatan yang ada di Indonesia. Dengan kata lain, banyak jembatan di Indonesia yang mengalami perubahan kelas jalan. Kondisi ini mengakibatkan dibutuhkannya evaluasi pada desain jembatan yang sudah ada. Jika jembatan dinilai sudah tidak layak untuk digunakan, pembongkaran dan pembangunan kembali jembatan bukanlah suatu opsi yang efektif, karena selain mahal, juga menganggu arus lalu lintas. Oleh karena itu, perkuatan jembatan menjadi opsi yang paling efektif. Perkuatan jembatan dengan metode prategang eksternal merupakan salah satu metode perkuatan yang efektif untuk mengatasi fenomena ini. Perkuatan jenis ini menggunakan kabel diluar rangka baja jembatan yang berguna untuk memperkuat struktur rangka jembatan. Dalam teori prategang eksternal, ada beberapa jenis bentuk trase kabel prategang. Pada penelitian ini, penulis memodelkan jembatan yang diperkuat menggunakan prategang eksternal dengan 5 bentuk trase kabel prategang yang berbeda-beda. Selanjutnya, Kelima model ini dibandingkan dengan model jembatan yang belum diperkuat dengan prategang eksternal. Analisis struktur pada peneltian ini menggunakan program SAP 2000. Variabel yang dilihat dari struktur jembatan setelah diperkuat adalah pengurangan tegangan yang terjadi pada setiap rangka batang jembatan. Pada akhir penelitian ini, dipilih 1 bentuk trase kabel prategang yang memberikan pengaruh terbesar dalam mengurangi tegangan yang terjadi pada rangka batang jembatan.
\end{abstract}

Kata kunci: jalan raya, jembatan, perkuatan, prategang eksternal, trase

\section{PENDAHULUAN}

\section{Latar Belakang}

Jembatan merupakan suatu struktur penting dalam infrastruktur jalan yang berfungsi untuk menghubungkan suatu ruas jalan yang terputus karena suatu rintangan. Rintangan tersebut biasa berupa sungai, jurang, lembah, dan danau. Jembatan sering menjadi komponen kritis dalam infrastruktur jalan raya karena menjadi penentu beban maksimum yang dapat dilalui ruas jalan tersebut

Di zaman yang semakin maju ini, pertumbuhan penduduk semakin meningkat dari tahun ke tahun, juga sedang dilaksanakan pembangunan di berbagai sektor, seperti ekonomi, sosial, dan industri. Hal ini menyebabkan terjadinya peningkatan beban pada jembatan yang ada di Indonesia. Kondisi ini mengakibatkan dibutuhkannya evaluasi pada desain jembatan keselamatan para pengguna infrastruktur jalan dalam menggunakan jembatan. Alasan ini juga diiringi dengan umur jembatan yang semakin tua dan desain pembebanan yang sudah tidak lagi ideal dengan kondisi yang ada saat ini. Dengan kata lain, dapat dikatakan banyak jembatan di Indonesia yang mengalami perubahan kelas jalan.

Menindaklanjuti fenomena diatas, dibutuhkan suatu metode untuk meningkatkan kapasitas beban jembatan dimana suatu jembatan harus dapat dibuat menjadi lebih kuat untuk mengakomodir pembebanan yang lebih besar. Pembongkaran dan pembangunan kembali jembatan baru dinilai kurang efisien. Selain menimbulkan gangguan aktivitas lalu-lintas suatu daerah, metode ini juga membutuhkan biaya yang cukup tinggi. Alasan ini membuat para ilmuwan mencari beberapa alternatif lain untuk memperkuat suatu jembatan tanpa membongkar jembatan eksisting. 
Salah satu metode perkuata jembatan yang cukup efektif yaitu dengan menggunakan prategag eksternal. Konsep perkuatan jembatan rangka baja dengan metode prategang eksternal yaitu baja yang diletakkan diluar elemen utama struktur rangka baja yang berfungsi untuk menekan struktur utama jembatan. Selanjutnya, gaya tekan ini membuat rangka batang jembatan mengalami pengurangan nilai tegangan. Pada skripsi ini, penulis ingin melakukan perbandingan antara lima kombinasi posisi trase kabel prategang eksternal pada jembatan. Jembatan yang digunakan pada pengerjaan skripsi ini adalah jembatan tipe Warren Truss dengan panjang bentang $30 \mathrm{~m}$. Dalam penelitian ini akan dilakukan analisis pengaruh perkuatan jembatan terhadap pengurangan tegangan rangka baja jembatan. Hal ini akan ditunjukkan dari perbandingan tegangan batang jembatan pada saat sebelum diperkuat dan setelah diperkuat dengan metode prategang eksternal. Dari kelima alternatif posisi trase tendon yang ada, akan dianalisis dengan beban yang sama dan dipilih satu alternatif terbaik yang memberikan nilai pengurangan tegangan rangka batang jembatan yang terbesar.

\section{Identifikasi Masalah}

Berdasarkan uraian latar belakang di atas, maka dapat diidentifikasi masalah sebagai berikut:

1. Terjadi peningkatan beban pada jembatan yang sudah ada.

2. Adanya perubahan kelas jalan pada jembatan.

3. Dibutuhkan perkuatan jembatan tanpa membongkar jembatan eksisting.

4. Adanya beberapa alternatif kombinasi posisi trase kabel tendon baja prategang.

\section{Rumusan Masalah}

Dari uraian yang ada di atas, maka rumusan masalah pada penulisan ini adalah:

1. Berapa besar tegangan rangka batang yang terjadi pada rangka baja jembatan setelah diperkuat dengan metode prategang eskternal?

2. Berapa besar pengurangan tegangan rangka batang jembatan setelah diperkuat dengan metode prategang eksternal?

3. Bagaimana bentuk trase tendon prategang yang menghasilkan hasil perkuatan terbesar?

\section{Tujuan Penelitian}

Tujuan dari penelitian ini adalah:

1. Mengetahui bentuk trase tendon prategang eksternal yang memberikan perkuatan jembatan terbesar.

2. Mengetahui berapa besar pengurangan tegangan rangka baja jembatan setelah diperkuat dengan prategang eksternal.

\section{Batasan Penelitian}

Dalam penyusunan makalah ini, ruang lingkup dan batasan masalah yang dibahas adalah:

1. Jenis jembatan yang dianalisis adalah jenis rangka baja tipe warren truss.

2. Metode perkuatan jembatan yang dibahas adalah metode prategang eksternal dimana tendon baja diletakkan pada struktur rangka baja jembatan.

3. Alternatif kombinasi posisi trase tendon prategang mengikuti alternatif yang ada di dalam pedoman perkuatan jembatan dengan metode prategang eksternal.

4. Pembebanan pada jembatan sesuai dengan peraturan pembebanan SNI 1725:2016.

5. Beban yang bekerja pada jembatan meliputi beban mati dan beban akibat kendaraan.

6. Sambungan rangka baja tidak diperhitungkan.

7. Pengecekan tegangan dilakukan pada rangka baja jembatan.

8. Analisis struktur rangka dilakukan dengan metode ASD (Allowable Stress Design).

9. Analisis struktur jembatan menggunakan bantuan Software SAP 2000.

\section{TINJAUAN PUSTAKA}

\section{Jembatan}

Jembatan adalah suatu konstruksi yang gunanya meneruskan jalan melalui suatu rintangan yang berada lebih rendah. Rintangan ini biasanya jalan lain berupa jalan air atau lalu lintas biasa. Jembatan yang berada diatas jalan lalu lintas biasanya disebut viaduct. Jembatan dapat digolongkan sebagai berikut: 
1. Jembatan - jembatan tetap.

2. Jembatan - jembatan dapat digerakkan.

Jembatan adalah suatu bangunan yang memungkinkan suatu jalan menyilang sungai/saluran air, lembah atau menyilang jalan lain yang tidak sama tinggi permukaannya. Dalam perencanaan dan perancangan jembatan sebaiknya mempertimbangkan fungsi kebutuhan transportasi, persyaratan teknis dan estetika-arsitektural yang meliputi: Aspek lalu lintas, Aspek teknis, Aspek estetika. (Supriyadi dan Muntohar, 2007)

\section{Jembatan Rangka Baja}

Menurut (Asiyanto, 2008) jembatan rangka baja adalah struktur jembatan yang terdiri dari rangkaian batang batang baja yang dihubungkan satu dengan yang lain. Beban atau muatan yang dipikul oleh struktur ini akan diuraikan dan disalurkan kepada batang - batang baja struktur tersebut, sebagai gaya - gaya tekan dan tarik, melalui titik - titik pertemuan batang (titik buhul). Garis netral tiap - tiap batang yang bertemu pada titik buhul harus saling berpotongan pada satu titik saja, untuk menghindari timbulnya momen sekunder.

Batang-batang rangka ini hanya memikul gaya dalam aksial (normal) tekan atau tarik, tidak seperti pada jembatan gelagar yang memikul gaya-gaya dalam momen lentur dan gaya lintang. Jembatan rangka baja telah menjadi kekuatan yang efektif dan efisien untuk jembatan bentang panjang lebih dari 150 tahun.

Keuntungan pemakaian material besi baja dalam pembangunan jembatan dibandingkan material beton dan kayu adalah:

a) Baja mempunyai kekuatan dan keliatan yang tinggi,

b) Ada jenis baja yang tahan terhadap cuaca, bahkan tidak perlu di cat.

c) Dari segi kekuatannya, bahan baja lebih murah dari beton ataupun kayu, sebab dengan kekuatannya memerlukan volume bahan lebih sedikit.

d) Rendahnya biaya pemasangan.

e) Jadwal konstruksi yang lebih cepat.

f) Tingkat keselamatan kerja tinggi.

g) Mudah dalam pemasangan.

h) Elemen struktur dapat dibuat di pabrik, dan dapat dilakukan secara besar-besaran.

i) Dapat dilakukan bongkar pasang dengan cepat, tanpa ada bahan terbuang.

j) Membutuhkan ruang kerja yang lebih sempit.

k) Dapat mengikuti bentuk-bentuk arsitektur.

1) Ramah lingkungan, dapat menggantikan posisi kayu sebagai bahan konstruksi.

\section{Prategang Eksternal}

Prinsip perkuatan dengan Prategang Eksternal adalah menyederhanakan penerapan beban aksial yang dikombinasikan dengan gaya angkat untuk meningkatkan kapasitas lentur dan geser dari struktur balok atau komponen. Peningkatan kekuatan yang diberikan dengan prategang eksternal dapat mereduksi defleksi dan vibrasi selama umur layannya. Sama seperti pada sistem prategang yang biasa dilakukan khususnya jembatan beton parategang, Prategang Eksternal menerapkan suatu gaya tekan yang dikombinasikan dengan momen eksentrisitas guna menambah kapasitas lentur serta memperbaiki kondisi retakan dari suatu gelagar. Penerapan system prategang ini dilakukan dengan pemasangan angker, tendon dan deviator pada struktur jembatan.

Perkuatan ini merupakan perkuatan yang universal karena dapat dilakukan untuk berbagai macam tipe struktur. Selain struktur beton dapat pula untuk struktur baja. Perkuatan dengan Prategang eksternal menyerdehanakan penerapan beban aksial yang dikombinasikan dengan gaya angkat untuk meningkatkan kapasitas lentur dan geser dari struktur balok atau komponen. Metode ini juga dapat digunakan untuk meningkatkan kapasitas dan umur layan.

\section{METODOLOGI PENELIITIAN}

\section{Kerangka Berpikir}

Seluruh langkah kerja yang akan dilakukan dalam penelitian ini dapat dilihat melalui kerangka berpikir yang dapat dilihat melalui gambar 1 . 

dengan Metode Prategang Eksternal Ditinjau dari Bentuk Trase Kabel Prategang

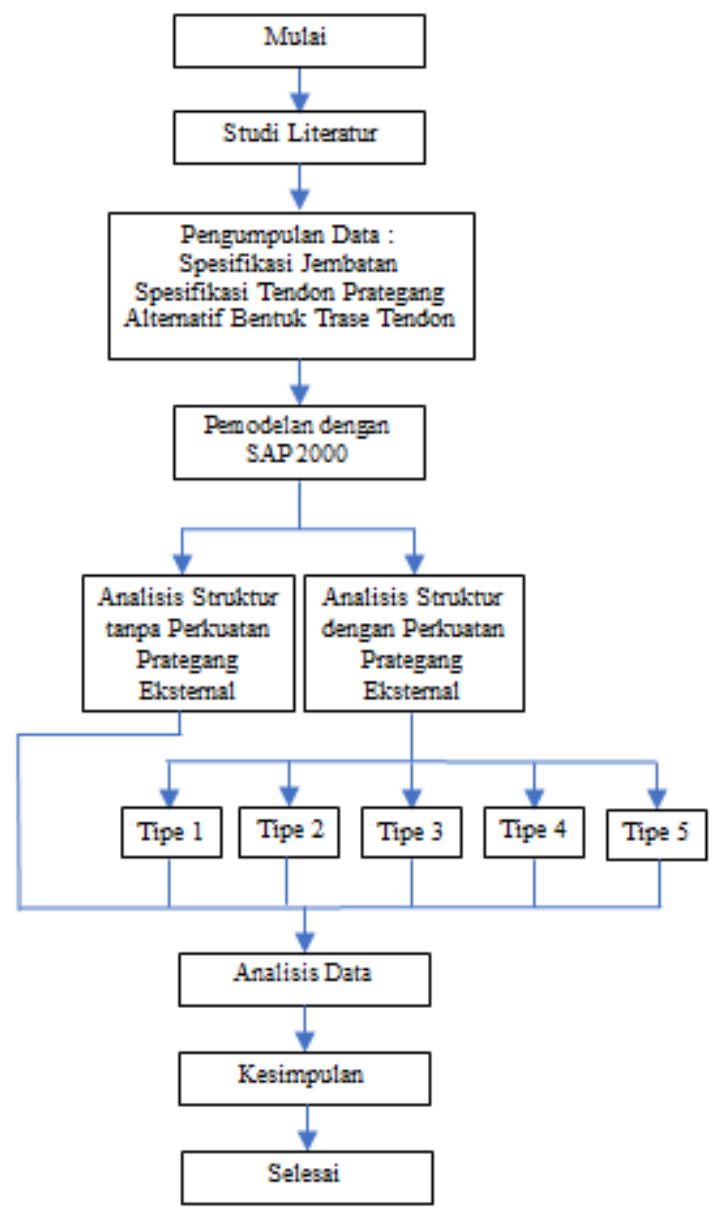

\section{Studi Literatur}

Studi literatur yang dilakukan dalam pengerjaan penelitian ini adalah dengan membaca jurnal-jurnal yang sudah ditulis mengenai jembatan rangka baja, perkuatan jembatan rangka baja, dan teori struktur baja. Ada juga peraturanperaturan yang penulis gunakan sebagai referensi dalam penelitian ini yaitu:

- $\quad$ Bridge Management System (BMS) 92

- $\quad$ SNI 1725 - 2016 berjudul Pembebanan pada jembatan

- Pedoman Konstruksi dan Bangunan (Pd T-03-2004-B) berjudul Perkuatan jembatan rangka baja Australia dengan metode prategang eksternal

- $\quad$ AISC 1989 berjudul Allowable Stress Design and Plastic Design

\section{Deskripsi Jembatan}

Struktur rangka baja dari jembatan yang digunakan dalam penelitian ini dapat dilihat pada Gambar 2 sampai gambar 4 berikut ini. Jembatan yang digunakan terdiri dari 10 jenis profil baja. Keterangan profil rangka baja dari jembatan dapat dilihat tabel 1 . 

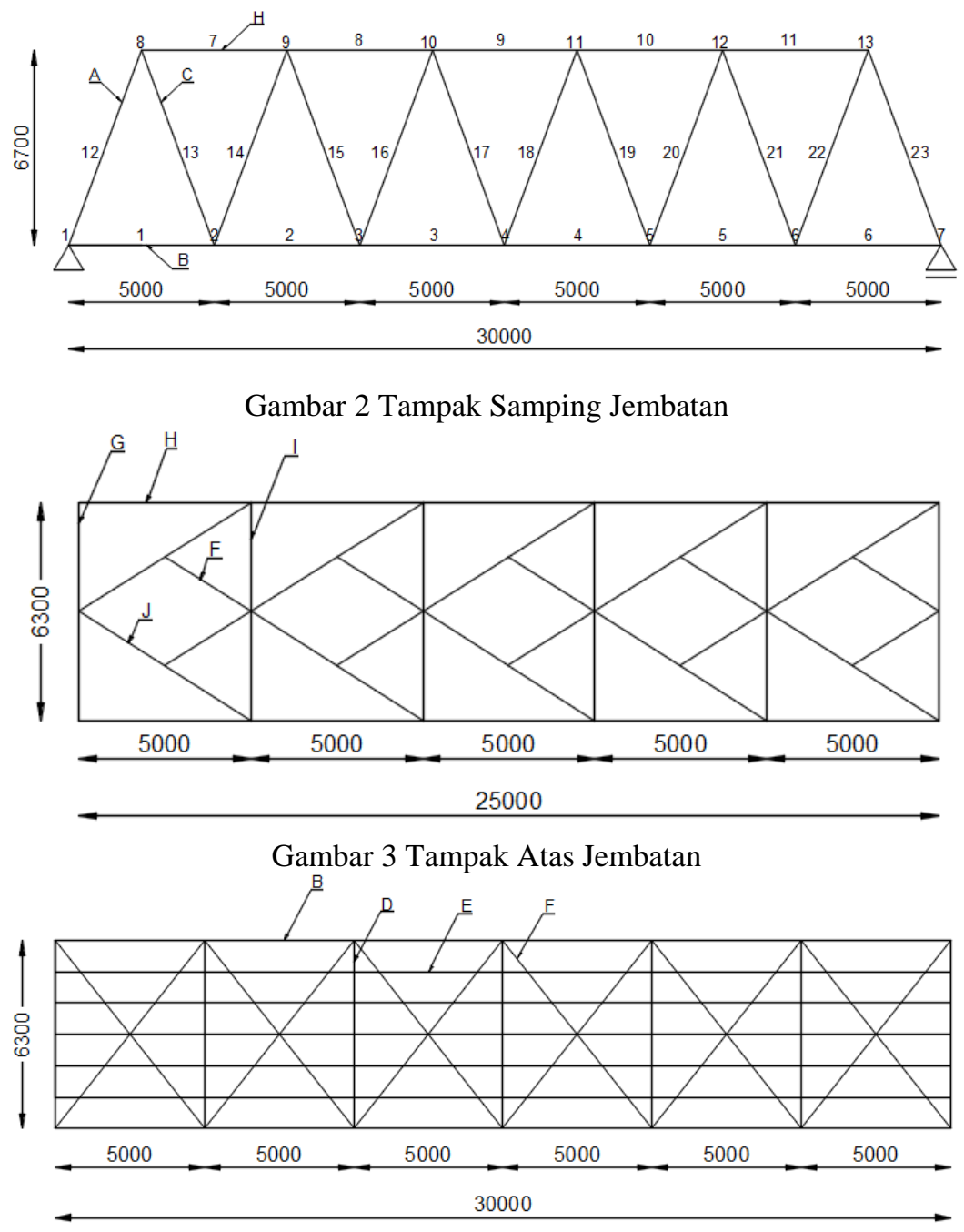

Gambar 4 Tampak Bawah Jembatan

Tabel 1 Profil Rangka Baja Jembatan

\begin{tabular}{|c|c|}
\hline KODE & PENAMPANG \\
\hline $\mathrm{A}$ & WF $350 \times 300 \times 10 \times 29$ \\
\hline $\mathrm{B}$ & WF $355 \times 350 \times 10 \times 11$ \\
\hline $\mathrm{C}$ & WF $350 \times 250 \times 10 \times 10$ \\
\hline $\mathrm{D}$ & WF $755 \times 267 \times 12 \times 12$ \\
\hline $\mathrm{E}$ & WF $500 \times 200 \times 10 \times 16$ \\
\hline $\mathrm{F}$ & L 100.100 .8 \\
\hline $\mathrm{G}$ & WF $405 \times 180 \times 20 \times 10$ \\
\hline $\mathrm{H}$ & WF $350 \times 300 \times 10 \times 10$ \\
\hline $\mathrm{I}$ & WF $355 \times 350 \times 10 \times 11$ \\
\hline $\mathrm{J}$ & L 150.100 .8 \\
\hline
\end{tabular}



dengan Metode Prategang Eksternal Ditinjau dari Bentuk Trase Kabel Prategang

\section{Perkuatan Prategang Eksternal}

Pada penelitian ini, ada 5 model jembatan yang berbeda. Perbedaan dari masing-masing model berdasarkan bentuk trase kabel prategang. Kelima model tersebut dapat dilihat pada gambar di bawah ini.
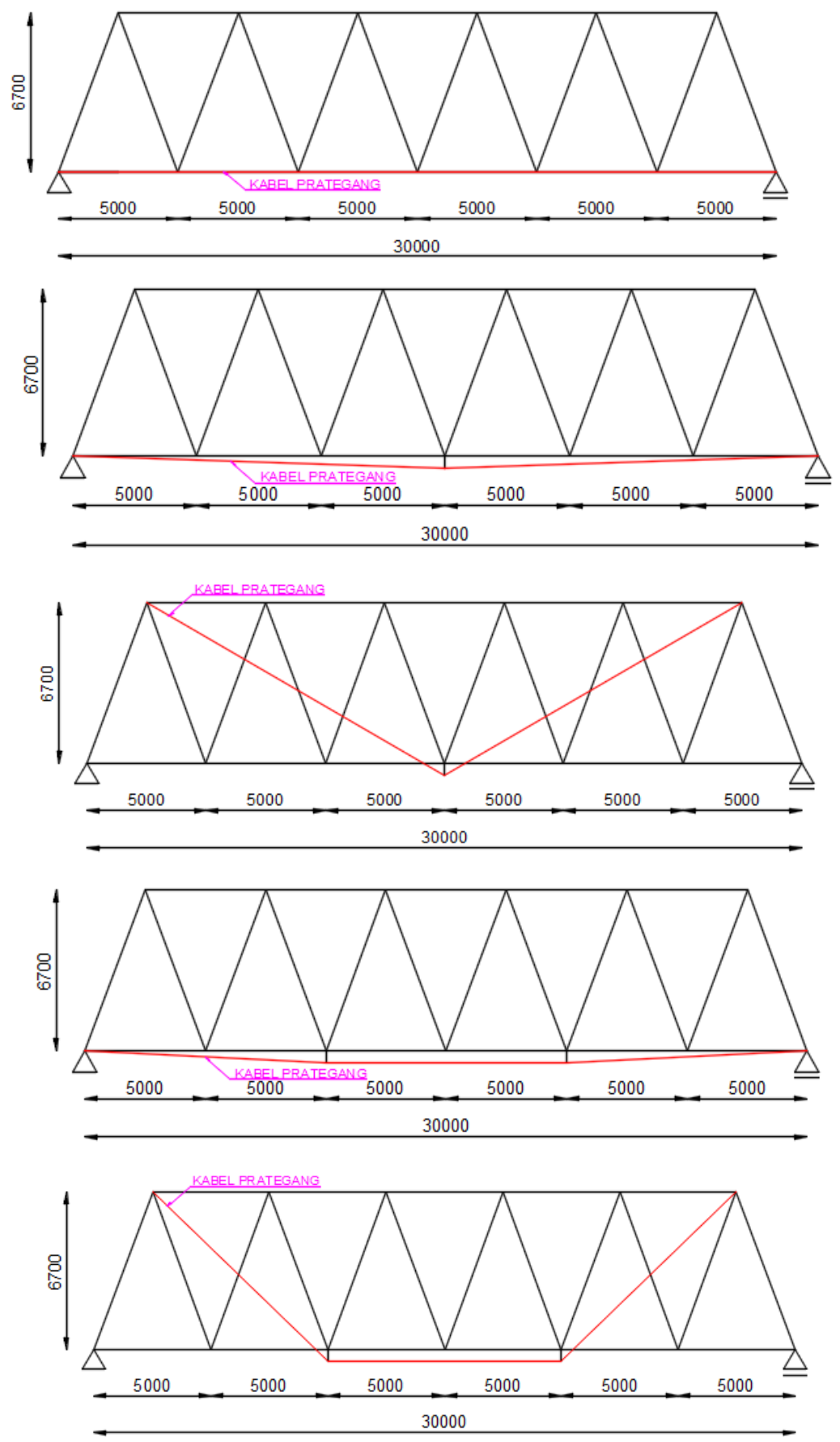

Gambar 5 Pemodelan Jembatan dengan Perkuatan Prategang Eksternal 


\section{Pembebanan Jembatan}

Beban yang bekerja pada jembatan meliputi 3 jenis beban yaitu beban mati, beban mati tambahan, dan beban hidup:

- Beban Mati berupa beban struktur jembatan. Nilai ini sudah dihitung secara otomatis oleh program

- Beban mati tambahan berupa beban pelat beton sebegai lantai kendaraan dan beban perkerasan aspal. Besarnya sebesar $0.59 \mathrm{t} / \mathrm{m}$ dengan berat jenis beton sebesar $2.4 \mathrm{ton} / \mathrm{m}^{3}$ dan berat jenis aspal sebesar 2.2 ton/ $\mathrm{m}^{3}$.

- Beban hidup pada jembatan berupa beban lalu-lintas dimana dibagi menjadi 2 kategori yaitu beban lajur dan beban truk

\section{Perhitungan Beban Hidup Jembatan}

- Beban lajur "D"

1. Beban Terbagi Rata (BTR)

Panjang Jembatan $(\mathrm{L})=30 \mathrm{~m}$, dimana $\mathrm{L} \leq 30 \mathrm{~m}$

maka, nilai $\mathrm{q}=9.0 \mathrm{kPa}$

Jadi, $\mathrm{q}_{\mathrm{BTR}}=9 \mathrm{kPa}=0.9 \mathrm{t} / \mathrm{m}^{2}$

Nilai $\mathrm{q}_{\mathrm{BTR}}$ di atas perlu dikalikan dengan $\mathrm{S}$ (lebar lajur)

$\mathrm{q}=\mathrm{q}_{\mathrm{BTR}} \times \mathrm{S}=0.9 \mathrm{t} / \mathrm{m}^{2} \times 2.75 \mathrm{~m}=2.475 \mathrm{t} / \mathrm{m}$

2. Beban Garis Terpusat (BGT)

Beban garis terpusat ditempatkan pada jembatan dengan intensitas sebesar $49.0 \mathrm{kN} / \mathrm{m}$ dan harus ditempatkan tegak lurus terhadap arah lalu lintas.

$\mathrm{P}_{\mathrm{BTR}}=49 \mathrm{kN} / \mathrm{m}=4.9 \mathrm{t} / \mathrm{m}$

Nilai $\mathrm{P}_{\mathrm{BTR}}$ di atas perlu dikalikan dengan $\mathrm{S}$ (lebar lajur)

$\mathrm{P}=\mathrm{P}_{\text {BTR }} \times \mathrm{S}=4.9 \mathrm{t} / \mathrm{m} \times 2.75 \mathrm{~m}=13.475$ ton

Nilai P di atas perlu dikalikan dengan Dynamic Load Allowance (DLA) sebesar 1.4

Jadi, $\mathrm{P}_{\mathrm{akhir}}=13.475$ ton $\mathrm{x} 1.4=18.865$ ton

- Beban Truk "T"

Sesuai dengan SNI 1725 - 2016, beban truk "T" terdiri dari kendaraan berat dengan 3 gandar. Skema pembebanan untuk beban truk "T" dapat dilihat pada Gambar 4.3. Nilai Berat tiap gandar perlu dikalikan dengan nilai Dynamic Load Allowance (DLA) sebesar 1.3. skema pembebanan truk dapat dilihat pada gambar di bawah ini.

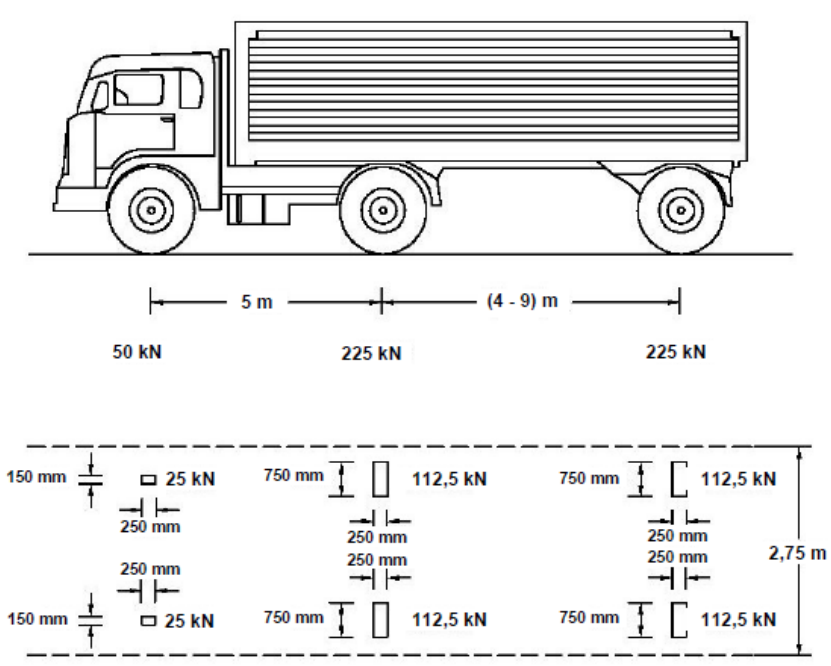

Gambar 6 Pembebanan Truk 

dengan Metode Prategang Eksternal Ditinjau dari Bentuk Trase Kabel Prategang

\section{HASIL DAN PEMBAHASAN}

\section{Hasil Gaya Batang}

Hasil output dari program berupa gaya batang jembatan dapat dilihat pada tabel di bawah ini.

Tabel 2 Hasil Gaya Batang

\begin{tabular}{|c|c|c|c|c|c|c|c|}
\hline \multicolumn{2}{|c|}{ BATANG } & \multicolumn{7}{|c|}{ GAYA BATANG (TON) } \\
\cline { 3 - 9 } & 1 & 15.4707 & 30.9414 & 52.5277 & 90.9875 & 158.986 & 280.915 \\
\hline \multirow{4}{*}{$\begin{array}{c}\text { BATANG } \\
\text { BAWAH }\end{array}$} & 2 & 37.4683 & 74.9366 & 126.52 & 219.289 & 383.277 & 677.503 \\
\cline { 2 - 8 } & 3 & 47.7973 & 95.5946 & 161.244 & 279.445 & 488.487 & 863.527 \\
\cline { 2 - 8 } & 4 & 47.7775 & 95.555 & 161.023 & 279.253 & 488.054 & 862.862 \\
\cline { 2 - 8 } & 5 & 38.1092 & 76.2184 & 128.479 & 222.78 & 389.368 & 688.366 \\
\cline { 2 - 8 } & 6 & 17.6069 & 35.2138 & 59.7207 & 103.94 & 181.267 & 320.421 \\
\hline \multirow{4}{*}{$\begin{array}{c}\text { BATANG } \\
\text { ATAS }\end{array}$} & 7 & -84.13 & -168.26 & -279.96 & -481.55 & -845.63 & -1495.4 \\
\cline { 2 - 8 } & 8 & -135.28 & -270.56 & -455.35 & -779.39 & -1370 & -2420 \\
\cline { 2 - 8 } & 9 & -152.58 & -305.16 & -518.28 & -883.8 & -1554.7 & -2743.6 \\
\cline { 2 - 8 } & 10 & -135.24 & -270.49 & -455.15 & -779.08 & -1369.5 & -2419 \\
\cline { 2 - 7 } & 11 & -83.721 & -167.44 & -279.39 & -479.8 & -842.91 & -1490.2 \\
\hline
\end{tabular}

\begin{tabular}{|c|c|c|c|c|c|c|c|c|}
\hline \multicolumn{2}{|c|}{ BATANG } & \multicolumn{7}{|c|}{ GAYA BATANG (TON) } \\
\cline { 2 - 9 } & LL "D" & TP & P1 & P2 & P3 & P4 & P5 \\
\hline \multirow{5}{*}{ BATANG } & 12 & -50.839 & -125.67 & -251.33 & -417.61 & -719.78 & -1263.1 & -2234.2 \\
\cline { 2 - 9 } & 13 & 46.2391 & 118.632 & 237.264 & 395.033 & 678.536 & 1192.2 & 2108 \\
\cline { 2 - 9 } & 14 & -39.209 & -85.452 & -170.9 & -293.05 & -503.16 & -881.66 & -1555.7 \\
\cline { 2 - 9 } & 15 & 30.4859 & 77.3845 & 154.769 & 265.638 & 450.893 & 793.915 & 1399.58 \\
\cline { 2 - 9 } & 16 & -26.302 & -42.599 & -85.198 & -152.48 & -263.98 & -459.06 & -808.25 \\
\cline { 2 - 9 } & 17 & 19.0847 & 33.1043 & 66.2086 & 117.677 & 202.97 & 353.752 & 622.931 \\
\cline { 2 - 9 } & 18 & 19.2499 & 33.7649 & 67.5298 & 121.574 & 208.353 & 363.692 & 639.575 \\
\cline { 2 - 9 } & 19 & -26.437 & -41.862 & -83.724 & -152.44 & -262.6 & -456.9 & -803.23 \\
\cline { 2 - 9 } & 20 & 30.5631 & 79.1321 & 158.264 & 273.161 & 461.988 & 814.281 & 1434.53 \\
\cline { 2 - 9 } & 21 & -39.266 & -84.211 & -168.42 & -290.69 & -498.38 & -873.29 & -1540.1 \\
\cline { 2 - 9 } & 22 & 44.6273 & 116.474 & 232.949 & 391.461 & 669.036 & 1176.97 & 2078.96 \\
\cline { 2 - 8 } & 23 & -53.958 & -127.51 & -255.03 & -425.61 & -734.6 & -1287.7 & -2277.3 \\
\hline
\end{tabular}

Selanjutnya, dilakukan pengecekan tegangan pada gaya batang maksimum yang terjadi pada masing-masing kategori rangka batang. Metode yang digunakan adalah ASD (Allowable Stress Design), dengan nilai tegangan izin sebesar $160 \mathrm{Mpa}$. Hasil perhitungan tegangan dapat dilihat pada tabel di bawah ini.

\begin{tabular}{|c|c|c|c|c|c|c|}
\hline \multirow{2}{*}{ BATANG } & \multicolumn{7}{|c|}{ TEGANGAN (MPa) } \\
\cline { 2 - 7 } & TP & P1 & P2 & P3 & P4 & P5 \\
\hline BATANG BAWAH & 50.9811 & -75.1802 & -73.5224 & 23.8612 & -76.1695 & 27.0116 \\
\hline BATANG & -114.9363 & -95.2004 & -100.5653 & -107.4003 & -98.2443 & -106.2457 \\
\cline { 2 - 7 } DIAGONAL & 168.1534 & 146.0869 & 144.7409 & 141.8944 & 141.8944 & 46.3174 \\
\hline BATANGATAS & -248.7220 & -225.5503 & -208.1589 & -278.1271 & -208.3920 & -228.3866 \\
\hline
\end{tabular}

Tabel 3 Hasil Perhitungan Tegangan

Hasil tegangan rangka batang yang didapat dari hasil perhitungan selanjutnya dibandingakan dengan tegangan rangka batang jembatan sebelum diperkuat. 
Jurnal Mitra Teknik Sipil

Vol. 1, No. 1, Agustus 2018: hlm 230-239

\begin{tabular}{|c|c|c|c|c|c|c|c|c|c|c|c|}
\hline \multirow[b]{2}{*}{ BATANG } & \multicolumn{10}{|c|}{ TEGANGAN (Mpa) } & \multirow[b]{2}{*}{$\begin{array}{c}\% \\
\text { SELISIH }\end{array}$} \\
\hline & TP & TIPE 1 & $\begin{array}{c}\% \\
\text { SELISIH }\end{array}$ & TIPE 2 & $\begin{array}{c}\% \\
\text { SELISIH }\end{array}$ & TIPE 3 & $\begin{array}{c}\% \\
\text { SELISIH }\end{array}$ & TIPE 4 & $\begin{array}{c}\% \\
\text { SELISIH }\end{array}$ & TIPE 5 & \\
\hline BATANG BAWAH & 50.9811 & 75.1802 & 47.4669 & 73.5224 & 44.2150 & 23.8612 & -53.1960 & 76.1695 & 49.4073 & 27.0116 & -47.0164 \\
\hline BATANG & 114.9363 & 95.2004 & -17.1711 & 100.5653 & -12.5034 & 107.4003 & -6.5567 & 98.2443 & -14.5228 & 106.2457 & -7.5612 \\
\hline DIAGONAL & 168.1534 & 146.0849 & -13.1240 & 144.7409 & -13.9233 & 141.8944 & -15.6161 & 141.8944 & -15.6161 & 46.3174 & -72.4553 \\
\hline BATANG ATAS & 248.7220 & 225.5503 & -9.3163 & 208.1589 & -16.3086 & 278.1271 & 11.8225 & 208.3920 & -16.2149 & 228.3866 & -8.1759 \\
\hline RATA-RATA & & & 1.9639 & & 0.3699 & & -15.8866 & & 0.7634 & & -33.8022 \\
\hline
\end{tabular}

Dari tabel di atas, dapat dilihat pada kolom \% selisih terdapat angka yang bernilai positif maupun negatif. Angka yang bernilai positif menggambarkan peningkatan gaya batang pada jembatan sesudah diperkuat dengan prategang eksternal, sebaliknya angka yang bernilai negatif menggambarkan penurunan nilai gaya batang pada jembatan yang sudah diperkuat.

Berdasarkan hasil yang didapatkan, bentuk trase tipe 5 memberikan efek pengurangan tegangan yang paling besar diantara semua tipe bentuk trase lainnya. Hal ini ditunjukkan dari rata-rata pengurangan tegangan batang sebesar $33.8022 \%$.

Sebaliknya, bentuk trase tendon 1,2, dan 4 memberikan efek peningkatan tegangan rangka batang. Tetapi jika dilihat per elemen rangka, hanya elemen batang diagonal yang mendapatkan efek pengurangan tegangan. Di sisi lain, ada batang bawah dan batang atas pada beberapa tipe bentuk trase yang mendapatkan pengaruh berupa peningkatan nilai tegangan. Sebagai contoh, pada perkuatan tipe 1,2, dan 4, batang bawah mengalami tegangan tekan yang melebihi tegangan tarik awal pada saat jembatan sebelum diperkuat. Hal ini menunjukkan terjadinya overstressing pada jembatan jika menggunakan bentuk-bentuk trase tendon tersebut.

\section{Perhitungan Cover Plate}

Pada perkuatan tipe yang kelima, walaupun memberikan pengurangan nilai tegangan terbesar, perkuatan tipe ini masih belum mampu untuk membuat rangka batang atas jembatan untuk memenuhi syarat tegangan. Setelah dilakukan perhitungan dengan metode trial and error, didapatkan ukuran cover plate sebesar $15 \mathrm{~mm}$ x $200 \mathrm{~mm}$ $($ Tebal $=15 \mathrm{~mm}$ dan lebar $=200 \mathrm{~mm})$ yang dipasang pada kedua sisi flens rangka batang baja jembatan.

\section{KESIMPULAN}

Dalam penelitian ini, kesimpulan yang dapat diambil adalah sebagai berikut:

- Pada model jembatan yang belum diperkuat, terdapat batang yang tidak memenuhi syarat tegangan izin, yaitu batang atas. Hal ini menjadi tanda bahwa jembatan perlu diperkuat agar dapat menjamin keselamatan pengguna jalan raya.

- Setelah dilakukan pengecekan terhadap tegangan rangka batang pada jembatan yang sudah diperkuat, didapatkan hasil bahwa ada beberapa rangka batang yang tidak memenuhi syarat tegangan izin, yaitu beberapa batang bawah, batang atas, dan batang diagonal tarik. Sebaliknya, dari hasil yang didapatkan, semua batang diagonal tekan memenuhi persyaratan tegangan izin yang berlaku.

- Model perkuatan prategang eksternal yang memberikan pengaruh paling besar dalam pengurangan tegangan rangka batang adalah model dengan bentuk trase tendon tipe 5. Hal ini dapat dilihat pada Tabel 4.16 dimana jembatan yang sudah diperkuat dengan bentuk trase tendon tipe 5, rata-rata pengurangan tegangan yang terjadi pada rangka batang jembatan mencapai $33.8022 \%$.

- Pada perkuatan prategang eksternal dengan tipe bentuk trase tendon 1,2, dan 4 terjadi overstressing pada gaya kabel prategang. Hal ini dapat dilihat pada batang bawah jembatan yang mengalami tegangan tekan lebih besar jika dibandingkan dengan tegangan tarik yang terjadi pada jembatan sebelum diperkuat. Sebagai contoh pada perkuatan dengan bentuk trase tendon tipe 2, tegangan pada rangka batang bawah yang sebelumnya bernilai 50.8911 MPa, menjadi -73.5224 MPa setelah diperkuat.

- Pada perkuatan yang menghasilkan pengurangan tegangan terbesar, yaitu perkuatan dengan bentuk trase tendon tipe 5, digunakan cover plate dengan tebal $15 \mathrm{~mm}$ dan lebar $200 \mathrm{~mm}$ pada kedua sisi flens batang atas agar batang tersebut dapat memenuhi syarat tegangan izin. 


\section{DAFTAR PUSTAKA}

AISC 1989. 1989. Allowable Stress Design and Plastic Design. American Institute of Steel Construction, Inc.

BMS 1992 Bagian 2. 1992. Bridge Management System. Direktorat Jenderal Bina Marga.

Burhan, Hannis. 2007. Buku Ajar: Struktur Baja. Jakarta: Jurusan Teknik Sipil Universitas Tarumanagara.

Darma, Edifrizal. Bahan Ajar: Struktur Baja II. Jakarta: Universitas Mercu Buana.

Elpian, Aleksander. Perancangan Struktur Jembatan Randusongo di Kabupaten Sleman, Propinsi Daerah Istimewa Yogyakarta. Skripsi. Univeristas Atma Jaya Yogyakarta. 2011.

Hansen, Friederich. Analisis Pengaruh Perkuatan Jembatan Rangka Baja Tipe Warren Truss dengan Metode Prategang Eksternal Terhadap Kapasitas Jembatan. Skripsi. Universitas Tarumanagara. 2018.

Imansyah, M. D., Faris Haqqul Anwar, Sugeng P. Budio, Roland Martin S.. Analisis Kemanan Jembatan Rangka Baja Soekarno-Hatta Malang Ditinjau dari Aspek Kesehatan, Tegangan Pelat Buhul, dan Simulasi Kebakaran. Skripsi. Universitas Brawijaya.

Pd T-03-2004. 2004. Perkuatan jembatan rangka baja Australia dengan metode prategang eksternal. Departemen Permukiman dan Prasarana Wilayah.

Rasidi, N., Diana Ningrum, Lalu Gusman S. W.. Analisis Alternatif Jembatan Rangka Baja (Studi Kasus: Jembatan Rangka Baja Soekarno-Hatta Malang). Skripsi. Universitas Tribhuwana Tunggadewi Malang.

SNI 1725-2016. 2016. Standar pembebanan untuk jembatan. Badan Standardisasi Nasional. Jakarta.

Supriyadi, B., Agus S. Muntohar. 2000. Jembatan. Yogyakarta: Betta Offset

Wibowo, Kevin. Analisis Pengaruh Kekakuan Kolom Terhadap Kehilangan Gaya Aksial Prategang pada Balok Prategang. Skripsi. Universitas Tarumanagara. 2018. 